\title{
Herbs in exercise and sports
}

\author{
Chee Keong Chen", Ayu Suzailiana Muhamad and Foong Kiew Ooi
}

\begin{abstract}
The use of herbs as ergogenic aids in exercise and sport is not novel. Ginseng, caffeine, ma huang (also called 'Chinese ephedra'), ephedrine and a combination of both caffeine and ephedrine are the most popular herbs used in exercise and sports. It is believed that these herbs have an ergogenic effect and thus help to improve physical performance. Numerous studies have been conducted to investigate the effects of these herbs on exercise performance. Recently, researchers have also investigated the effects of Eurycoma longifolia Jack on endurance cycling and running performance. These investigators have reported no significant improvement in either cycling or running endurance after supplementation with this herb. As the number of studies in this area is still small, more studies should be conducted to evaluate and substantiate the effects of this herb on sports and exercise performance. For instance, future research on any herbs should take the following factors into consideration: dosage, supplementation period and a larger sample size.
\end{abstract}

Keywords: herbs, ginseng, caffeine, ephedrine, Eurycoma longifolia Jack

\section{Background}

According to botanists, 'herb' is defined as a softstemmed plant which dies after flowering, whereas herbalists define an 'herb' as any part of a plant which can be used for medicine, cooking, cosmetics and as a scent or dye. In nature, there are many types of herbs that can be found and have been used traditionally for many purposes. Athletes are among those who use herbs for their own benefit. They believe that some herbs may help them to improve their performance, speed up recovery, maintain health and fitness during intense periods of training, increase muscle mass and reduce body fat. Ginseng, caffeine, ephedrine and recently Eurycoma longifolia Jack are among the popular herbs used to enhance exercise and sports performance. In this article, we review some of the studies of these herbs to investigate their effects on exercise and sports performance.

'Ginseng' is a general name for the plant genus Panax. Some of the members of genus are Panax ginseng, Panax quinquefolius, Panax notoginseng and Panax japonicus. Among these plants, Panax ginseng, also known as Chinese or Korean ginseng, is the one which is most widely used [1]. Ginseng is available in various forms, such as whole root, root powder, teas and

\footnotetext{
* Correspondence: ckchen@kck.usm.my

Sports Science Unit, School of Medical Sciences, Universiti Sains Malaysia, 16150 Kubang Kerian, Kelantan, Malaysia
}

tinctures, as well as standardized root extracts containing known amounts of ginsenosides in every batch [2]. Ginseng roots contain approximately 13 glycosylated steroidal saponins (ginsenosides) which are the probable active agents $[1,3,4]$. Ginseng is thought to be a tonic that can improve vitality, health and longevity. Separation of ginsenosides and administration to animals has revealed activities which stimulate the central nervous system [2-6]. Other probable functions of ginseng include increased production of corticotropin and cortisol in animals and humans and anabolic actions in animals [2-4,7-9]. In addition, ginseng has been shown to possess antioxidant properties whereby it scavenges hydroxyl radical and inhibits lipid peroxidation [10]. Ginseng has also been touted as possessing a stimulant effect and thus improves alertness and decreases fatigue and stress [11]. Consequently, various possible mechanisms of ginseng ingestion have been postulated to contribute to the enhancement of human sports performance.

In a number of animal studies, ginseng has been reported to improve exercise performance. Researchers in some other animal studies, however, have reported that the use of large doses or parenteral administration could weaken extrapolation of these scientific data to humans $[3,4,12]$. In exercise and sports science, ginseng is believed to be a physical performance enhancer [1]. However, a review of the available data on the effects of 
ginseng on human exercise performance reveals doseresponse and duration effects, which may account for the equivocal results reported [13]. Its chronic use has been believed to improve cardiorespiratory function and lower lactate concentration in the blood in addition to improving physical performance [14]. Nevertheless, it has been reported that its benefits were best seen in individuals in poor physical condition [4].

Many study investigators have found that ginseng can increase exercise duration until exhaustion during forced exercise trials $[4,14]$. This was believed to be due to stress adaptation via ginseng supplementation [11]. Panax ginseng has been investigated extensively for its stress-attenuating activity [15]. It is a well-known adaptogen and has been shown to be effective in attenuating stress-induced adverse effects in astronauts and soldiers [16]. Rai and colleagues [17] demonstrated that Panax ginseng has potent adaptogenic activity that is mediated by regulation of pituitary adrenocorticotropic hormone secretion to combat stress. This adaptation to stress may increase exercise time to exhaustion [1]. For example, Liang et al. [18] reported that, in untrained adults, consumption of one 1,350-mg Panax notoginseng capsule per day for 30 days improved their endurance time by more than 7 minutes and lowered their maximal mean blood pressure and maximal oxygen consumption $\left(\mathrm{VO}_{2} \max \right)$ at the 24th minute during endurance cycling exercise. McNaughton et al. [19] conducted a placebocontrolled cross-over study in which the subjects were given Chinese ginseng, Siberian ginseng or placebo supplements ( $1 \mathrm{~g} /$ day for 6 weeks for each supplement). They reported that Chinese ginseng significantly increased maximal oxygen consumption, postexercise recovery and pectoral and quadriceps strength, but handgrip strength did not change after the supplementation regimen. Furthermore, it has been shown that a single dose of Panax ginseng (200 mg) can modulate circulating blood glucose level, enhance cognitive performance on a mental arithmetic task and ameliorate the increase in subjective feeling of mental fatigue during sustained intense cognitive processing [20].

It has been reported that the use of ginseng does not lead to any positive test results for banned substances after urine testing of elite athletes, although ginsenosides and their metabolites were detectable in the sera and urine of athletes following the ingestion of ginseng [21,22]. Panax ginseng has certain ergogenic properties that may improve both physical and mental performance, provided that the dosage is adequate $(\geq 200 \mathrm{mg} /$ day $)$ and the supplementation period is of sufficient duration $(\geq 8$ weeks). In addition, supplementation of Panax ginseng has been proven to be safe on the basis of animal toxicity studies which demonstrated that ginseng does not result in teratogenicity or mutagenicity $[3,4]$.
Researchers in related studies have revealed that caffeine supplementation can improve performance at varying intensities and modalities of exercise [23], and evidence of its effects on submaximal exercise has also been well-documented [24]. However, its effect on intermittent sprint performance is still lacking [23]. It has been reported that plasma concentration of caffeine is maximal 1 hour after ingestion and returns to normal 6 hours after ingestion [25]. Thus, for ergogenic purposes, a dose of caffeine ranging from 2 to $9 \mathrm{mg} / \mathrm{kg}$ body mass has been suggested to be effective, and the caffeine should be taken at least 1 hour prior to exercise or competition [26].

The effect of caffeine on endurance was reported in a study where there was a significant increase $(44 \%)$ in endurance running performance after athletes ingested 9 $\mathrm{mg} / \mathrm{kg}$ body mass of caffeine 1 hour prior to exercise [27]. Caffeine is a well-documented stimulant of the central nervous system as well as the cardiovascular and respiratory systems. It is believed that caffeine ingestion increases blood catecholamine concentration $[28,29]$. Furthermore, its ergogenic effect on sports performance is also attributed to its effect on substrate availability, namely, free fatty acids [30]. Increases in free fatty acid concentration in turn lead to a glycogen-sparing effect [28] because the body's energy system will start using free fatty acid as a primary source of fuel. A recent study demonstrating endurance enhancement with caffeine supplementation ( $5 \mathrm{mg} / \mathrm{kg}$ body weight) showed a significantly higher level of plasma free fatty acids in the caffeine trial compared to the placebo trial [31]. Glycogen sparing can delay the onset of exhaustion; consequently, physical performance can be enhanced [32,33]. Researchers in two studies who used the needle biopsy procedure demonstrated a glycogen-sparing effect following caffeine supplementation [34,35]. In addition, Kamat et al. [36] proposed that the ergogenic effect of caffeine could be due to its antioxidant property. However, more studies need to be conducted to substantiate this claim.

Collomp et al. [37] investigated the beneficial effects of caffeine ingestion on sprint performance in trained and untrained swimmers. Subjects' swimming velocity and blood lactate concentrations were observed to determine the plausible effects of caffeine. The subjects were required to perform 100-metre freestyle swimming twice at maximal speed: once after ingestion of $250 \mathrm{mg}$ of caffeine and the other after placebo ingestion. These two tests were separated by 20 minutes of passive recovery. The study results showed that the swimming velocity of the trained swimmers was significantly improved after caffeine ingestion and that maximal blood lactate concentration was significantly enhanced in both untrained and trained subjects after caffeine ingestion. 
Caffeine is also associated with mental alertness and mood. Yeomans and colleagues [38] found that ingestion of 1 and $2 \mathrm{mg} / \mathrm{kg}$ caffeine at breakfast decreased reaction time and improved rated mental alertness, thus increasing performance. They also found that a $1 \mathrm{mg} / \mathrm{kg}$ dose of caffeine could increase performance accuracy. Similarly, ingestion of $1 \mathrm{mg} / \mathrm{kg}$ caffeine 60 minutes after breakfast in the subjects who did not consume any caffeine during breakfast also improved their rated mental alertness and decreased their reaction time. However, doubling caffeine ingestion did not improve those effects; the effects of caffeine in the subjects who ingested caffeine during breakfast and 60 minutes after breakfast were similar to those who ingested caffeine once, either only during breakfast or 60 minutes after breakfast. This study demonstrated that the effects of caffeine occur only in the caffeine-deprived subjects.

Chinese ephedra, or 'ma huang', is a sporophyte herb that has also been studied for its effects on exercise performance [39-43]. It is found mainly in Pakistan, China and northwestern India. The active ingredients consist of ephedrine and related alkaloids [44]. It is a sympathomimetic alkaloid because it mimics epinephrine effects and stimulates the sympathetic nervous system [45]. Receptors for ephedrine in human body are found on most cells, including the heart, lungs and blood vessels. Ephedrine was claimed to have ergogenic properties whereby it was believed to improve aerobic performance and endurance by reducing fatigue, increasing alertness, improving reaction time and increasing strength [41]. However, a number of studies in which investigators examined the effects of ephedrine or pseudoephedrine on exercise performance in humans have demonstrated that there was no enhancement of performance when the normal dosages $(\geq 120 \mathrm{mg} /$ day) considered safe were ingested [46-48]. Sidney and Lefcoe [46] gave 24mg ephedrine supplements to 21 males and reported no significant differences compared with placebo in muscle strength, endurance or power, speed, lung function, hand-eye coordination, reaction time, anaerobic capacity and cardiorespiratory endurance, maximal oxygen consumption and ratings of perceived exertion. Swain et al. [48] administered 1 and $2 \mathrm{mg} / \mathrm{kg}$ pseudoephedrine or 0.33 and $0.66 \mathrm{mg} / \mathrm{kg}$ phenylpropanolamine or placebo to ten trained cyclists who were then required to undergo testing on a bicycle ergometer and a urine drug test. There were no significant differences in maximal oxygen consumption, ratings of perceived exertion, blood pressure, peak pulse rate or time to exhaustion between trials. Similarly, Gillies et al. [47] reported no significant changes in a cycling time trial performance or muscle function when ten subjects were given either $120 \mathrm{mg}$ of pseudoephedrine or placebo in a randomized, doubleblind, placebo-controlled cross-over study.
It is postulated that the positive effects of ephedrine can be seen when it is combined with caffeine on the basis of studies in which caffeine was believed to potentiate the effects of ephedrine [39,41]. For instance, the combination of caffeine and ephedrine has been found to increase the time to exhaustion during a standard high-intensity cycle ergometer exercise test [39]. Another study showed that after ingesting $75 \mathrm{mg}$ of ephedrine and $375 \mathrm{mg}$ of caffeine, there was a significant decrease in the completion of a $3.2-\mathrm{km}$ run [40]. In another study, $10 \mathrm{~km}$ of running on a treadmill was 1 minute faster after the ingestion of ephedrine or a combination of ephedrine and caffeine when compared to the placebo trial [42]. These data raise speculation that the effect of the combination of caffeine and ephedrine occurs as a result of central nervous system stimulation. Furthermore, it has been reported that ingestion of this combination decreased the rate of perceived exertion during high-intensity exhaustive exercise [49]. Individual ephedrine alkaloids do not seem to augment physical performance, but, when combined with caffeine, they apparently have a synergistic effect that prolongs exercise time to exhaustion.

Eurycoma longifolia Jack is one of the herbs found in Malaysia. It is commonly known as 'tongkat ali' in Malaysia and as 'pasak bumi' in Indonesia. It is also referred to as 'Malaysian ginseng' because it is wellknown among various ethnic groups in Malaysia as a treatment for various diseases and enhancing health [50]. Eurycoma longifolia Jack is a tall, single-stemmed, slender, shrubby, slowly growing tree, and it can be found on sandy soil. It belongs to the Simaroubaceae family and grows wildly in Southeast Asian countries, that is, Malaysia, Indonesia, Thailand, Myanmar, Laos and Cambodia [50-52].

This herb has been used as an anticoagulant for complications during childbirth, a treatment for dysentery [52], an aphrodisiac [53,54], an antimalarial agent $[55,56]$, an antibacterial ointment $[57,58]$, an anticancer medicine [58], an antihyperglycaemic therapy [59] and an anxiolytic [60]. The pharmacological activity of this plant is actually attributed to these various quassinoids and also to the squalene derivatives biphenylneolignans, tirucallane-type triterpenes, canthine-6-1 and $\beta$-carboline alkaloids [51]. Mohd Tambi [61] reported that consumption of water-soluble extract of Eurycoma longifolia Jack, even at a high dose of $600 \mathrm{mg}$, is nontoxic in humans.

Published scientific data regarding the effects of Eurycoma longifolia Jack on exercise performance are scarce. Nevertheless, the acute effects of an herbal drink containing Eurycoma longifolia Jack on cycling endurance performance were investigated $[62,63]$. In this previous study, subjects were given a low dosage of Eurycoma 
longifolia Jack (approximately $0.67 \mathrm{mg}$ of Eurycoma longifolia Jack per trial) during endurance cycling performance. The young, trained male cyclists ingested either an herbal drink or placebo and cycled as long as possible at $70 \% \mathrm{VO}_{2} \max$ for the first hour and at $80 \%$ $\mathrm{VO}_{2} \max$ thereafter until exhaustion during the experimental trials. It was reported that there was no significant improvement in cycling performance or in the physiological responses between the two trials in this study. It is speculated that the results could be due to the inadequate concentration of Eurycoma longifolia Jack in the drink $(0.1 \mathrm{mg} / 100 \mathrm{ml}$ of drink) which was given to the subjects during the cycling trials.

Subsequently, we conducted another study to investigate the effects of Eurycoma longifolia Jack on endurance running performance with a higher dosage of this herb and a longer supplementation duration [64]. Twelve recreational athletes were recruited to participate in this study, in which they were asked to consume two capsules of the supplement (75 mg of Eurycoma longifolia Jack per capsule) or placebo capsules daily for 7 days before and again 1 hour prior to the exercise trial. We observed that this amount of Eurycoma longifolia Jack (150 mg daily for 7 days) had no beneficial effects on the participants' endurance running performance and physiological responses. However, it has been reported that Eurycoma longifolia Jack supplementation (150 mg for 5 weeks) can increase muscle strength [65]. Therefore, we believe that the supplementation period and maybe the dosage used in our previous study were still insufficient to elicit the beneficial effects of Eurycoma longifolia Jack on endurance performance and physiological responses. Thus further study at higher dosages and for longer supplementation periods may be warranted to determine its effects on exercise and sports performance.

Some of these herbs have been shown to have beneficial effects on psychological states. For example, ginseng has positive effects on stress, caffeine improves mental alertness and mood and Eurycoma longifolia Jack has anxiolytic (that is, antianxiety) properties. However, how these changes in psychological states as a result of herbal supplementation affect sports performance has not been well-studied. Hence further studies could also focus on the effects of these herbs on psychological states and determine if these effects (if any) are associated with a concomitant improvement in sports performance.

\section{Conclusions}

Table 1 summarises the selected studies on the effects of ginseng, caffeine, ephedrine, a combination of caffeine and ephedrine, and Eurycoma longifolia Jack in exercise and sports performance. It can be observed from the

Table 1 Selected studies on the effects of ginseng, caffeine, ephedrine, combination of caffeine and ephedrine, and Eurycoma longifolia Jack in exercise and sports

\begin{tabular}{|c|c|c|c|c|}
\hline Studies & Population & Herbal treatment & Exercise & Key findings \\
\hline \multicolumn{5}{|l|}{ Panax ginseng } \\
\hline $\begin{array}{l}\text { Kim et al., } 2005 \\
{[14]}\end{array}$ & $\begin{array}{l}\text { Seven healthy } \\
\text { males }\end{array}$ & $\begin{array}{l}2 \mathrm{~g} \text { of Panax ginseng extract or } \\
\text { placebo three times per day for } 8 \\
\text { weeks }\end{array}$ & $\begin{array}{l}\text { Exhaustive incremental exercise on } \\
\text { treadmill }\end{array}$ & $\begin{array}{l}\text { Increased exercise duration until } \\
\text { exhaustion and facilitation of } \\
\text { recovery from exhaustive exercis }\end{array}$ \\
\hline $\begin{array}{l}\text { Liang et al., } \\
2005 \text { [18] }\end{array}$ & $\begin{array}{l}29 \text { untrained } \\
\text { adults (ages } \\
20 \text { to } 35 \text { years } \\
\text { old) }\end{array}$ & $\begin{array}{l}\text { For } 30 \text { days: } 1,350 \text { mg/day Panax } \\
\text { ginseng or placebo }\end{array}$ & $\begin{array}{l}\text { Endurance exercise on cycle } \\
\text { ergometer at } 65 \% \text { to } 70 \% \mathrm{VO}_{2} \text { peak. } \\
\text { Exercise intensity increased by } 30 \mathrm{~W} \\
\text { at every } 5 \text {-minute interval after first } \\
35 \text { minutes of exercise until } \\
\text { exhaustion. }\end{array}$ & $\begin{array}{l}\text { Improved endurance exercise tin } \\
\text { to exhaustion with Panax ginsen } \\
\text { consumption }\end{array}$ \\
\hline \multicolumn{5}{|l|}{ Caffeine } \\
\hline $\begin{array}{l}\text { Ping et al., } 2010 \\
\text { [31] }\end{array}$ & $\begin{array}{l}\text { Nine male } \\
\text { recreational } \\
\text { runners }\end{array}$ & $\begin{array}{l}1 \text { hour prior to exercise: } 5 \text { mg/kg } \\
\text { body weight of caffeine or placebo }\end{array}$ & $\begin{array}{l}\text { Running to exhaustion at } 70 \% \\
\mathrm{VO}_{2} \text { max on a motorised treadmill in } \\
\text { the heat }\left(31^{\circ} \mathrm{C} \text { and } 70 \% \text { relative }\right. \\
\text { humidity) }\end{array}$ & $\begin{array}{l}\text { Improved endurance running } \\
\text { performance in the heat }\end{array}$ \\
\hline $\begin{array}{l}\text { Bell and } \\
\text { McLellan, } 2003 \\
{[24]}\end{array}$ & Nine males & $\begin{array}{l}1 \text { hour before exercise: } 5 \text { or } 2.5 \text { mg/ } \\
\mathrm{kg} \text { body mass of caffeine or placebo }\end{array}$ & $\begin{array}{l}\text { Exercise rides to exhaustion on cycle } \\
\text { ergometer at } 80 \% \mathrm{VO}_{2} \mathrm{max} \\
\text { performed in the morning and } 5 \\
\text { hours later on the same day }\end{array}$ & $\begin{array}{l}\text { Increased exercise time to } \\
\text { exhaustion }\end{array}$ \\
\hline $\begin{array}{l}\text { Cohen et al., } \\
1996[28]\end{array}$ & $\begin{array}{l}\text { Seven } \\
\text { endurance- } \\
\text { trained } \\
\text { competitive } \\
\text { road racers } \\
\text { (ages } 23 \text { to } 51 \\
\text { years old) }\end{array}$ & $\begin{array}{l}0,5 \text { or } 9 \mathrm{mg} / \mathrm{kg} \text { body mass of } \\
\text { caffeine }\end{array}$ & $\begin{array}{l}\text { Maximal effort of } 21-\mathrm{km} \text { road racers } \\
\text { outdoors in hot and humid } \\
\text { conditions }\end{array}$ & $\begin{array}{l}\text { Race performance in high heat } \\
\text { stress not affected by caffeine } \\
\text { supplementation }\end{array}$ \\
\hline
\end{tabular}


Table 1 Selected studies on the effects of ginseng, caffeine, ephedrine, combination of caffeine and ephedrine, and Eurycoma longifolia Jack in exercise and sports (Continued)

\begin{tabular}{|c|c|c|}
\hline $\begin{array}{l}\text { Collomp et al., } \\
1992 \text { [37] }\end{array}$ & $\begin{array}{l}\text { Seven trained } \\
\text { and seven } \\
\text { untrained } \\
\text { subjects }\end{array}$ & $\begin{array}{l}\text { Single dose of } 250 \mathrm{mg} \text { of caffeine o } \\
\text { placebo }\end{array}$ \\
\hline $\begin{array}{l}\text { Costill et al., } \\
1978[25]\end{array}$ & $\begin{array}{l}\text { Nine } \\
\text { competitive } \\
\text { cyclists }\end{array}$ & $\begin{array}{l}\text { Ingestion of coffee containing } 339 \\
\text { mg of caffeine or exercise without } \\
\text { caffeine }\end{array}$ \\
\hline $\begin{array}{l}\text { Graham and } \\
\text { Spriet, } 1991 \text { [27] }\end{array}$ & $\begin{array}{l}\text { Seven trained } \\
\text { competitive } \\
\text { runners }\end{array}$ & $\begin{array}{l}1 \text { hour before exercise: } 9 \mathrm{mg} / \mathrm{kg} \\
\text { body mass of caffeine or placebo }\end{array}$ \\
\hline $\begin{array}{l}\text { Schneiker et al., } \\
2006[23]\end{array}$ & $\begin{array}{l}\text { Ten male } \\
\text { team sport } \\
\text { athletes }\end{array}$ & $\begin{array}{l}6 \mathrm{mg} / \mathrm{kg} \text { body mass of caffeine or } \\
\text { placebo } 1 \text { hour before exercise }\end{array}$ \\
\hline
\end{tabular}

Ephedrine

Sidney and

Lefcoe, 1977

[46]

21 healthy males (ages

to 30 years

old)

Caffeine +

ephedrine

Bell and Jacobs, Nine male

1999 [40] recreational

runners

Bell et al., 200012 healthy

[49]

untrained

males

Bell et al., 1998 Eight males

[39]

Bell et al., 200212 subjects

[42]

Williams et al, 2008 [43]

Nine

resistance-

trained male

participants
2 hours before trials: combination of $375 \mathrm{mg}$ of caffeine and $75 \mathrm{mg}$ of ephedrine or placebo

1.5 to 2 hours before exercise: 5 $\mathrm{mg} / \mathrm{kg}$ body mass of caffeine plus $0.8 \mathrm{mg} / \mathrm{kg}$ body mass of ephedrine, $4 \mathrm{mg} / \mathrm{kg}$ body mass of caffeine plus $1 \mathrm{mg} / \mathrm{kg}$ body mass of ephedrine, 4 $\mathrm{mg} / \mathrm{kg}$ body mass of caffeine plus

$0.8 \mathrm{mg} / \mathrm{kg}$ body mass of ephedrine, or placebo

1.5 hours before exercise: 5 mg/kg body mass of caffeine, $1 \mathrm{mg} / \mathrm{kg}$ body mass of ephedrine, combination of both caffeine and ephedrine, or placebo

$4 \mathrm{mg} / \mathrm{kg}$ body mass of caffeine, 0.8 $\mathrm{mg} / \mathrm{kg}$ body mass of ephedrine, combination of both caffeine and ephedrine, or placebo

45 minutes before exercise: $300 \mathrm{mg}$ of caffeine, $300 \mathrm{mg}$ of caffeine plus $60 \mathrm{mg}$ of ephedrine, or $300 \mathrm{mg}$ of glucose placebo

Eurycoma

longifolia Jack

Muhamad et al., 12 recreational Two capsules per day containing 75 2010 [64]

male athletes

(age $23.3 \pm 3.7$

years old SD)

mg of Eurycoma longifolia Jack or

placebo for 7 days before and

another two capsules 1 hour before exercise trial

Ooi et al., 2001 Six male

[62], 2003 [63] cyclists
$2 \times 100$-metre freestyle swims at maximal speed separated by 20 minutes of passive recovery

Exercise until exhaustion on a bicycle ergometer at $80 \% \mathrm{VO}_{2}$ max

Four exercise trials at approximately $85 \% \mathrm{VO}_{2}$ max: two trials of running to exhaustion and two trials of cycling to exhaustion.

Two 36-minute halves, with each half composed of $18 \times 4$-second sprints and 2 minutes of active recovery at $35 \% \mathrm{VO}_{2}$ peak between each sprint

Muscle strength, endurance and power exercise
Trained subjects exhibited significant improvement in swimming velocity after caffeine supplementation

Cycling time with caffeine ingestion greater than non-caffeine fluid ingestion

Endurance time increased with caffeine supplementation in both exercise modes

Total amount of sprint work performed and mean peak power score achieved during sprints were greater with caffeine ingestion in both exercise halves

No effect on any of the measurements of physical work capacity
Exercise on a cycle ergometer at a maximal power output until exhaustion

10-km run in a climatic suite at $12^{\circ} \mathrm{C}$ to $13^{\circ} \mathrm{C}$ on treadmill while wearing a helmet and backpack weighing 11 kg. Speed was regulated by subjects.

Maximal strength exercise of bench press (BP) at one repetition maximum (1 RM) and latissimus dorsi pull-down (LP) at 1 RM. Each subject also performed repeated repetitions at $80 \%$ of 1 RM on both $\mathrm{BP}$ and LP until exhaustion.

60 -minute run on treadmill at $60 \%$ $\mathrm{VO}_{2}$ max followed by 20 -minute time trial

Cycling at 70\% $\mathrm{VO}_{2}$ max for the first hour and $80 \% \mathrm{VO}_{2}$ max thereafter until exhaustion
Only the combination of caffeine and ephedrine led to a significantly longer time to exhaustion than placebo

Running time decreased in ephedrine and combination of ephedrine and caffeine trials. Running pace increased in ephedrine compared with nonephedrine groups over the last $5 \mathrm{~km}$ of the run.

Increased alertness and enhanced mood after supplementation of combination of caffeine and ephedrine. No differences in muscle strength, endurance or peak aerobic power.

Running distance during time trial with Eurycoma longifolia Jack was not different from placebo. Physiological responses were also not different between trials.

No significant improvement in cycling performance or physiological responses per $100 \mathrm{ml}$ of drink (about $0.67 \mathrm{mg}$ of Eurycoma per trial) or placebo drink during exercise 
data in this table that researchers have used various types of herbs to determine their effectiveness in enhancing sports performance. To date, the findings regarding their purported ergogenic effects are still inconclusive. The reason for these equivocal findings could be due to the differences in physiological responses of each individual toward the supplementation of these herbs. For example, there could be differences in terms of absorption, transport and storage of the active ingredients in the body of the participants in the studies. Furthermore, individual differences in physical attributes such as fitness level, body composition, age and sex could have resulted in varied responses toward the types of herbs consumed. Nevertheless, our review of the available literature led us to the following conclusions.

Panax ginseng, when administered at an adequate dosage (between 200 and $400 \mathrm{~g} /$ day) for a period of longer than 8 weeks may improve physical performance.

Caffeine consumption 1 hour prior to exercise at a prescribed dosage of 2 to $9 \mathrm{mg} / \mathrm{kg}$ body mass may prolong exercise time to exhaustion. Ma huang did not exert any ergogenic effect on sports performance when it was taken alone, but there is some evidence of improved physical performance when it is combined with caffeine, .

Eurycoma longifolia Jack, or 'tongkat ali', has not appeared to elicit any ergogenic effect on endurance performance in a limited number of studies of these herbs. However, future studies of this herb are definitely warranted because there might be a dose-dependent response and the supplementation duration of the previous studies might have been too short.

\begin{abstract}
Authors' contributions
All authors participated in the design of the study of Eurycoma longifolia Jack. AS and FK searched for more articles and journals related to the effects of supplements on exercise and sports performance. All authors read and selected relevant information and data from these articles and journals that were included in the text of this review. AS prepared the first draft of this review. FK and CK revised the draft manuscript that was submitted to the editorial board of this journal. CK made the necessary amendments that were recommended by the reviewers. All authors read and approved the final manuscript.
\end{abstract}

\section{Competing interests}

The authors declare that they have no competing interests.

Received: 11 April 2011 Accepted: 8 March 2012

Published: 8 March 2012

\section{References}

1. Kennedy DO, Scholey AB: Ginseng: potential for the enhancement of cognitive performance and mood. Pharmacol Biochem Behav 2003, 75:687-700.

2. Popov IM, Goldwag WJ: A review of the properties of clinical effects of ginseng. Am J Chin Med (Gard City N Y) 1973, 1:263-270.

3. Carr CJ: Natural Plant Products that Enhance Performance and Endurance Hillsdale, NJ: Lawrence Erlbaum Associates; 1986, 138-192.

4. Bahrke MS, Morgan WP: Evaluation of the ergogenic properties of ginseng. Sports Med 1994, 18:229-248.
5. Takagi K, Saito H, Nabata H: Pharmacological studies of Panax ginseng root: estimation of pharmacological actions of Panax ginseng root. Jpn J Pharmacol 1972, 22:245-259.

6. Samira MM, Attia MA, Allam M, Elwan O: Effect of the standardized ginseng extract G115 on the metabolism and electrical activity of the rabbit's brain. J Int Med Res 1985, 13:342-348.

7. Yamamoto $M$, Takeuchi N, Kumagai A, Yamamura Y: Stimulatory effect of Panax ginseng principles on DNA, RNA, protein and lipid synthesis in rat bone marrow. Arzneimittelforschung 1977, 27:1169-1173.

8. Odani T, Ushio Y, Arichi S: The effect of ginsenosides on adrenocorticotropin secretion in primary culture of rat pituitary cells. Planta Med 1986, 9:112-118.

9. Grandhi A, Mujumdar AM, Patwardhan B: A comparative pharmacological investigation of ashwaggandha and ginseng. J Ethnopharmacol 1994, 44:131-135.

10. Zhing $G$, Jiang $Y$ : Calcium channel blockage and anti-free radical actions of ginsenosides. Chin Med J 1997, 110:28-29.

11. Ahuja A, Goswami A, Adhikari A, Ghosh AK: Evaluation of effects of revital on physical performance in sportsmen. Indian Pract 1992, 45:685-688.

12. Bucci LR: Dietary substances not required in human metabolism. Nutrients as Ergogenic Aids for Sports and Exercise Boca Raton, FL: CRC Press; 1993, 83-90.

13. Bucci LR: Selected herbals and human exercise performance. Am J Clin Nutr 2000, 72(suppl):624S-636S.

14. Kim SH, Park KS, Chang MJ, Sung JH: Effects of Panax ginseng extract on exercise-induced oxidative stress. J Sports Med Phys Fitness 2005, 45:178-182.

15. Gaffney BT, Hugel HM, Rich PA: The effects of Eleutherococcus senticosus and Panax ginseng on steroidal hormone indices of stress and lymphocyte subset numbers in endurance athletes. Life Sci 2001, 70:431-442.

16. Brekhman II, Dardymov IV: New substances of plant origin which increase non-specific resistance. Annu Rev Pharmacol 1969, 9:419-430.

17. Rai D, Bhatia G, Sen T, Palit G: Anti-stress effects of Ginkgo biloba and Panax ginseng: a comparative study. J Pharmacol Sci 2003, 93:458-464.

18. Liang MTC, Podolka TD, Chuang WJ: Panax notoginseng supplementation enhances physical performance during endurance exercise. J Strength Cond Res 2005, 19:108-114.

19. McNaughton L, Egan G, Caelli G: A comparison of Chinese and Russian ginseng as ergogenic aids to improve various effects of physical fitness. Int Clin Nutr Rev 1989, 90:32-35.

20. Reay JL, Kennedy DO, Scholey AB: Effects of Panax ginseng, consumed with and without glucose, on blood glucose levels and cognitive performance during sustained 'mentally demanding' tasks. $J$ Psychopharmacol 2006, 20:771-781.

21. Cui JF, Garle M, Björkhem I, Eneroth P: Determination of aglycones of ginsenosides in ginseng preparations sold in Sweden and in urine samples from Swedish athletes consuming ginseng. Scand J Clin Lab Invest 1996, 56:151-160.

22. Cui JF, Björkhem I, Eneroth P: Gas chromatographic-mass spectrometric determination of 20(S)-protopanaxadiol and 20(S)-protopanaxatriol for study on human urinary excretion of ginsenosides after ingestion of ginseng preparations. J Chromatogr B Biomed Sci App/ 1997, 689:349-355.

23. Schneiker KT, Bishop D, Dawson B, Hackett LP: Effects of caffeine on prolonged intermittent-sprint ability in team-sport athletes. Med SC Sports Exerc 2006, 38:578-585.

24. Bell DG, McLellan TM: Effect of repeated caffeine ingestion on repeated exhaustive exercise endurance. Med Sci Sports Exerc 2003, 35:1348-1354.

25. Costill DL, Dalsky GP, Fink WJ: Effects of caffeine ingestion on metabolism and exercise performance. Med Sci Sports 1978, 10:155-158.

26. Kovacs EM, Stegen JHCH, Brous F: Effects of caffeinated drinks on substrate metabolism, caffeine excretion, and performance. J Appl Physiol 1998, 85:709-715.

27. Graham TE, Spriet LL: Performance and metabolic responses to a high caffeine dose during prolonged exercise. J Appl Physiol 1991, 71:2292-2298.

28. Cohen BS, Nelson AG, Prevost MC, Thompson GD, Marx BD, Morris GS Effects of caffeine ingestion on endurance racing in heat and humidity. Eur J Appl Physiol Occup Physiol 1996, 73:358-363.

29. Jackman M, Mendling P, Friars D, Graham TE: Metabolic catecholamines and endurance response to caffeine during intense exercise. J Appl Physiol 1996, 81:1658-1663. 
30. Bellet S, Kershbaum A, Aspe J: The effects of caffeine on free fatty acids. Arch Intern Med 1965, 116:750-752.

31. Ping WC, Keong CC, Bandyopadhyay A: Effects of acute supplementation of caffeine on cardiorespiratoy responses during endurance running in a hot and humid climate. Indian J Med Res 2010, 132:36-41.

32. Ivy JL, Costill DL, Fink WJ, Lower RW: Influence of caffeine and carbohydrate feedings on endurance performance. Med Sci Sports 1979, 11:6-11.

33. Conlee RK: Muscle glycogen and exercise endurance: a twenty-year perspective. Exerc Sport Sci Rev 1987, 15:1-28.

34. Essig D, Costill DL, Van Handel PJ: Effects of caffeine ingestion on utilization of muscle glycogen and lipid during leg ergometer cycling. Int J Sports Med 1980, 1:86-90.

35. Erickson MA, Schwarzkopf RJ, McKenzie RD: Effects of caffeine, fructose, and glucose ingestion on muscular glycogen utilization during exercise. Med Sci Sports Exerc 1987, 19:579-583.

36. Kamat JP, Boloor KK, Devasagayam TP, Jayashree B, Kesavan PC: Differential modification by caffeine of oxygen-dependent and independent effects of $y$-irradiation on rat liver mitochondria. Int I Radiat Biol 2000, 76:1281-1288

37. Collomp K, Ahmaidi S, Chatard JC, Audran M, Préfaut C: Benefits of caffeine ingestion on sprint performance in trained and untrained swimmers. Eur J Appl Physiol Occup Physiol 1992, 64:377-380.

38. Yeomans MR, Ripley T, Davies LH, Rusted JM, Rogers PJ: Effects of caffeine on performance and mood depend on the level of caffeine abstinence. Psychopharmacology (Berl) 2002, 164:241-249.

39. Bell DG, Jacobs I, Zamecnik J: Effects of caffeine, ephedrine and their combination on time to exhaustion during high-intensity exercise. Eur $J$ Appl Physiol Occup Physiol 1998, 77:427-433.

40. Bell DG, Jacobs I: Combined caffeine and ephedrine ingestion improves run times of Canadian Forces Warrior Test. Aviat Space Environ Med 1999, 70:325-329.

41. Powers ME: Ephedra and its application to sport performance: Another concern for the athletic trainer. J Athl Train 2001, 36:420-424.

42. Bell DG, McLellan TM, Sabiston CM: Effect of ingesting caffeine and ephedrine on 10-km run performance. Med Sci Sports Exerc 2002, 34:344-349.

43. Williams AD, Cribb PJ, Cooke MB, Hayes A: The effect of ephedra and caffeine on maximal strength and power in resistance-trained athletes. J Strength Cond Res 2008, 22:464-470.

44. Zhang JS, Tian Z, Lou ZC: [Quality evaluation of twelve species of Chinese ephedra (ma huang)] [in Chinese]. Yao Xue Xue Bao 1989, 24:865-871.

45. DiPasquale M: Stimulants and adaptogens: part 1. Drugs Sports 1992, 1:2-6.

46. Sidney $\mathrm{KH}$, Lefcoe NM: The effects of ephedrine on the physiological and psychological responses to submaximal and maximal exercise in man. Med Sci Sports 1977, 9:95-99.

47. Gillies H, Derman WE, Noakes TD, Smith P, Evans A, Gabriels G: Pseudoephredrine is without ergogenic effects during prolonged exercise. J Appl Physiol 1996, 81:2611-2617.

48. Swain RA, Harsha DM, Baenziger J, Saywell RM Jr: Do pseudoephedrine or phenylpropanolamine improve maximum oxygen uptake and time to exhaustion? Clin J Sport Med 1997, 7:168-173.

49. Bell DG, Jacobs I, McLellan TM, Zamecnik J: Reducing the dose of combined caffeine and ephedrine preserves the ergogenic effect. Aviat Space Environ Med 2000, 71:415-419.

50. Jaganath IB, Teik NL: Herbs: The Green Pharmacy of Malaysia Kuala Lumpur, Malaysia: Vinpress Sdn Bhd and Malaysian Agriculture Research and Development Institute (MARDI); 2000, 45-46.

51. Ang HH, Cheang HS, Yusof AP: Effects of Eurycoma longifolia Jack (Tongkat Ali) on the initiation of sexual performance of inexperienced castrated male rats. Exp Anim 2000, 49:35-38.

52. Osman A, Jordan B, Lessard PA, Muhammad N, Haron MR, Riffin NM, Sinskey AJ, Rha C, Housman DE: Genetic diversity of Eurycoma longifolia inferred from single nucleotide polymorphisms. Plant Physiol 2003, 131:1294-1301.

53. Ang HH, Sim MK: Eurycoma longifolia Jack enhances libido in sexually experienced male rats. Exp Anim 1997, 46:287-290.

54. Ang HH, Lee KL, Kiyoshi M: Sexual arousal in sexually sluggish old male rats after oral administration of Eurycoma longifolia Jack. J Basic Clin Physiol Pharmacol 2004, 15:303-309.
55. Chan KL, O'Neill MJ, Phillipson JD, Warhurst DC: Plants as sources of antimalarial drugs. Part 31: Eurycoma longifolia. Planta Med 1986, 52:105-107.

56. Ang $\mathrm{HH}$, Chan $\mathrm{KL}$, Mak JW: In vitro anti-malarial activity of quassinoids from Eurycoma longifolia against Malaysian chloroquine-resistant Plasmodium falciparum isolates. Planta Med 1995, 61:177-178.

57. Farouk AE, Benafri A: Antibacterial activity of Eurycoma longifolia Jack: a Malaysian medicinal plant. Saudi Med J 2007, 28:1422-1424.

58. Tee $\Pi$, Cheah YH, Hawariah LP: F16, a fraction from Eurycoma longifolia Jack extract induces apoptosis via a caspase-9-independent manner in MCF-7 cells. Anticancer Res 2007, 27:3425-3430.

59. Husen R, Pihie AH, Nallappan M: Screening for antihyperglycaemic activity in several local herbs of Malaysia. J Ethnopharmacol 2004, 95:205-208.

60. Ang HH, Cheang HS: Studies on the anxiolytic activity of Eurycoma longifolia Jack roots in mice. Jpn J Pharmacol 1999, 79:497-500.

61. Mohd Tambi MI: Standardized water soluble extract of Eurycoma longifolia (L100) on men's health. Int J Androl 2005, 28(Suppl 1):25-44.

62. Ooi FK, Singh R, Sirisinghe RG, Ang BS, Sahil Jamalullail SM: Effects of a herbal ergogenic drink on cycling performance in young cyclists. Mal J Nutr 2001, 7:33-40

63. Ooi FK, Singh R, Sirisinghe RG, Ang BS, Sahil Jamalullail SM: Effects of a herbal drink on cycling endurance performance. Mal J Nutr 2003, 10:78-85.

64. Muhamad AS, Keong CC, Kiew OF, Abdullah MR, Lam CK: Effects of Eurycoma longifolia Jack supplementation on recreational athletes' endurance running capacity and physiological responses in the heat. Int J Appl Sports Sci 2010, 22:1-19.

65. Hamzah S, Yusof A: The ergogenic effects of Eurycoma longifolia Jack: a pilot study [abstract 7]. Br J Sports Med 2003, 37:465-466.

doi:10.1186/1880-6805-31-4

Cite this article as: Chen et al: Herbs in exercise and sports. Journal of Physiological Anthropology 2012 31:4.

\section{Submit your next manuscript to BioMed Central and take full advantage of:}

- Convenient online submission

- Thorough peer review

- No space constraints or color figure charges

- Immediate publication on acceptance

- Inclusion in PubMed, CAS, Scopus and Google Scholar

- Research which is freely available for redistribution

Submit your manuscript at www.biomedcentral.com/submit
Ciomed Central 